\title{
SOM DET VERKLIGEN VAR Barbro Alving (Bang) i dagböcker och brev
}

\section{Av Elisabeth Stenborg, universitetslektor i litteraturvetenskap}

\author{
Länk till presentation av Elisabeth Stenborg
}

Barbro Alving föddes den 12 januari 1909 i det så kallade Skandalhuset i Uppsala, i en litterär och kulturell miljö. Hennes far var den kände filosofie doktorn Hjalmar Alving, som bl.a. gav ut en länge använd litteraturhistorisk lärobok för gymnasiet: Svensk litteraturhistoria. Den förelåg 1932 och kom sedan ut i flera upplagor. Vi hade den i mitten av 50-talet, när jag gick i gymnasiet. Hjalmar Alving var också en flitig översättare av isländska sagor.

Modern, Fanny Alving, gav ut humoristiska folklivsberättelser, skrev visor ochöversatte franska romaner. Hon hade börjat med att skriva seriös litteratur men fått så nedgörande kritik av Oscar Levertin att hon helt övergick till kåserier och annat lättare stoff. Hon medarbetade i skämttidningen Strix under signaturen "Maja X". Hon introducerade också den första kvinnliga svenska detektiven i boken Josefssons på Drottninggatan, 1918. Modern var mycket noga med att påpeka, att huset faktiskt hette Skandalhuset redan innan yngsta dottern Barbro, i familjen kallad Bappo, föddes. Båda föräldrarna hade mycket humor, en gåva som gick i arv till såväl Bappo som till den två år äldre systern Beat-Sofi, kallad Bojan eller Borra i familjen. I hemmet vistades då och då även halvbrodern Anders Norrman från Fanny Alvings tidigare äktenskap. Barndomsbilder på Barbro Alving visar en liten allvarlig flicka med glasögon. (I treårsåldern blev hon nämligen kolossalt vindögd, vilket korrigerades med dessa glasögon.)

Efter tio ganska sorglösa år i Uppsala flyttade familjen till Stockholm, omsider till Odengatan 42, senare till en villa i Nockeby i Bromma. Somrarna tillbringade man mestadels i Fanny Alvings lilla stuga på Stallarholmen i Mälaren. Barbro var aldrig särskilt förtjust i motion och sågs gärna ligga och lata sig i gräset. Den enda motion som hon gillade var cykelåkning. Bägge flickorna sattes i Whitlockskas samskolan, där fadern hade blivit rektor. Barbro Alving fann det besvärligt att ha fadern så nära inpå sig. Hon ville hellre ägna sig åt kamratlivet eller skriva i skoltidningen "Veni, vidi ..." än åt att läsa läxor. Redan som 11-åring hade hon klart för sig att hon ville bli journalist. Systern BeałSofi hade däremot tidigt bestämt, att hon skulle bli lärare som pappa. Barbro hade sina journalistdrömmar men fadern var djupt bekymrad över hennes brist på studieintresse. Hon brukade också skämtsamt berätta att "av någon anledning vägde jag 80 kilo vid 18 år", men det var inte alltid som hon förmådde skämta om sitt yttre. Som tonåring upplevde hon sig mestadels som en naturkatastrof.

Barbro Alving tog studenten 1928 och skrev in sig vid Stockholms högskola men blev snart volontär på Stockholms Dagblad. Hon blev redaktionssekreterare på veckotidningen Idun samma år. År 1931 återupptog hon sina akademiska studier, som hon avslutade 1934, dock utan examen. Samma år blev hon nämligen medarbetare i Dagen Nyheter, där hon stannade ända till 1959, då hon sade upp sig i protest mot att DN och dess chefredaktör Herbert Tingsten propagerade för svenska kärnvapen. Hon hade medarbetat i VeckoJournalen sedan 1942 men nu blev hon fast knuten till denna tidning, och hon förblev den trogen i nästan 20 år, tills hon lämnade aktiv tidningstjänst 1978. En del reportage finns samlade i boken Klipp ur nuets historia, 1982. Barbro Alving skrev också flitigt kåserier under signaturen "Käringen mot strömmen". Ett trettiotal kåseriböcker är utgivna. Hon blev tidigt pacifist och deltog på femtitalet aktivt i kampen mot att Sverige skulle skaffa sig 
kärnvapen, så aktivt att hon offrade sin anställning. Civilkurage är en av Bangs kännemärken. Också på ett annat sätt tog hon konsekvenserna av sin pacifistiska övertygelse, nämligen att hon vägrade att delta i civilförsvaret. Denna vägran renderade henne en månads fängelse. Intryck från den månaden har hon redovisat i boken Dagbok från Långholmen, 1956.

Lars Lagerstedt skriver i sin minnesruna över Barbro Alving i Anno 1987 att Bang var en av landets mest uppmärksammade och mångsidiga journalister. Intet var henne främmande. Hon gjorde frontreportage från finska vinterkriget 1939 och redan tidigare från spanska inbördeskriget. Hon var på plats i Norge våren 1940 och i Ungern vid revolten 1956. Hon gjorde reportageresor i USA, i Vietnam, i Afrika och på olika håll i Fjärran Östern. Men hon gjorde också reportage från kungliga bröllop och begravningar och mycket annat. Lars Lagerstedt skriver att hon engagerade sig hårt i alla de uppdrag som hon åtog sig. Han prisar hennes glasklara stil, fylld av känsla och oförskräckta ställningstaganden men också ofta av en barsk humor. Hon kämpade för fred och frihet, mot krig och våld och förtryck. Enlig Lagerstedt blev hon ett stilbildande föredöme för många yngre journalister. Nationalencyklpedien skriver att hennes journalistik präglas av "djup humor och humanism" .

Förutom reportage och kåserier ägnade sig Barbro Alving också åt att recensera både film (under signaturen "Miss Bio") och deckare och verkade också som översättare. Dessutom medverkade hon flitigt i radion, både med reportage och egna program. På sensommaren 1958 mötte hon Gunnel Vallquist, som blev hennes vägledare till katolicismen. Under pingsten 1959 konverterade hon. I ett brev till sin dotter skriver hon: "Jag har kommit hem efter 30 års sökande". Hon avled den 22 januari 1987.

Detta är yttre data och allmänna omdömen om Barbro Alvings journalistiska gärning. I de fyra delar av hennes dagböcker och brev, som kommit ut postumt, redigerade av dottern Ruffa Alving-Olin samt Birgit Petri under den gemensamma rubriken Personligt kan man följa Barbro Alvings liv från 1927 till 1959 och brytningen med DN. Barbro Alving hade tänkt ge ut sina memoarer och arbetade med detta projekt de sista tio åren av sitt liv Hon hade tänkt kalla memoarerna Som det verkligen var, och det skulle bli en memoarbok helt olik den som hon redan hade givit ut. Den hetteDet kom aldrig i tidningen, där hon berättat minnen och dråpliga situationer ur yrkeslivet. Den här självbiografien skulle se djupare. Till dottern Ruffa sade hon att hon tänkte "sticka hål på myten Bang. Jag vill berätta om människan Barbro Alving och hennes liv. Som det verkligen var. Och sanningen är inte alltid smickrande." Hon var med Ruffa Alvings ord trött på att vara myten Bang, en levande legend "den lysande reportern, roliga kåsören, kloka radiorösten." $\mathrm{Nu}$ ville hon "göra upp räkningen med sitt liv och sin s.k. gärning för det är ju det memoarer handlar om." Hon hann inte berätta om sitt liv. Våren 1983 drabbades hon avafasi och kunde inte längre skriva. Kvar fanns allt det material som hon lämnade efter sig. Tydligen hade hon samlat på allt från skoluppsatser till taxikvitton, brev från kända och okända, också egna brev som hon lyckats få tillbaka, kassaböcker och tidningsklipp, fulltecknade reportageblock och vad hon själv kallade "nattlappar", noteringar som hon gjort under långa, sömnlösa nätter. Det mesta av materialet hamnade så småningom på Kvinnohistoriska samlingarna i Göteborg, enligt Barbro Alvings egen önskan.

Ruffa Alving skriver i varje volym en insiktsfull inledande orientering. Den andra utgivaren, Birgit Petri, var också hon journalist och vän till Barbro Alving.

Den första dagboksanteckningen är daterad 19 januari 1927. Den unga författarinnan skriver en inledande allmän reflexion, som jag tänkte citera:

Det är det värsta med dagböcker, att man aldrig kan skrivaprecis vad man menar. Åtminstone inte jag. Och ännu mindre säga det. Jag har så grov och på något sätt stark röst, det blir aldrig så fritt och vackert som jag tänker. Och det är så tråkigt, för det är kanske mycket därför som pappa tror att jag bara är ytlig och karaktärslös och inte har någon smak utan bara tramsar med tiden. 
Det har han inte rätt i, det tror jag jag törs säga. För jag minns i somras, när jag cyklade ensam ikring på vägarna, hur det gick opp för mig vad mitt liv är och vad jag vill göra det till. Jag vill ställa det i skönhetens tjänst. Jag vill allt vackert i livet, bättre kan jag inte säga det.

Mitt liv. Ibland fyller de orden mig med en känsla, som gör att jag vill gråta. Jag vet inte varför. Men om man överhuvudtaget tänker på sådant, jag gör det nästan jämt, mitt i nöjen och bland folk och så, är man väl inte hopplöst ytlig? Och det att jag tramsar med tiden, detär inte bara trams. Jag känner någon sorts samband med allt ungt och nytt och fritt, jag förstår unga människors sätt att handla mycket mer än pappa, det gör jag absolut. Jag kan inte se att det är så förbannat viktigt med konvenans och tradition och sådant, jag beundrar passion och lidelse och sådant obetingat. Som när människor gör saker och ting, galna och okloka och brottsliga och vanvettiga saker för sin kärleks skull. Jag önskar bara att jag var mäktig att känna så starkt att jag kunde detsamma. Det vet jag inte än om jag kan men jag tror det.

Nu slutar jag om sådant här idag, men det blir nog mera, för jag blir inte lugn förrän jag får skriva ner det och se om mina tankar tål vid att läsas igenom om någon tid. Kan jag hjälpa att jag själv är det som intresserar mig mest av allt och att oron för mitt eget liv fyller mig nästan var minut. /---/ Men fast oron plågar mig outsägligt, så är jag glad, för jag tror den visar att jag vill något och jag tror, att man kan vad man vill. Det är bara det att jag inte vet vad jag vill.

I marginalen till de tre första ungdomsdagböckerna hade Barbro Alving skrivit: "bör tas med en nypa salt." Hon utvecklar tankegången i ett inlägg i Femina, där hon bland annat framhåller att unga människor har en tendens att mest skriva ner dystra tankar och olyckligheter. "Av ljus eller helt vanlig hygglig vardag kommer föga med i en ung människas kollationering av sin tillvaro i ensamhet på kammaren. Att mamma var rolig och pappa var snäll och det gick rätt skapligt i plugget är ingenting att skriva upp. /---/ Någon som läser mina svarta vaxduksböcker kan måhända tro att här har vi en mycket intressant ung människa, genom åren stadd i en utveckling i ständig kamp mot tungsinne, melankolier, kärleksbekymmer och menstruationsont. Sånt fanns. Men som dominans har det svår slagsida. Så intressant var man inte. Det må väl jag veta." Barbro Alving hade en stor portion självironi som synes!

Jag skall ta några citat från år 1927, då Barbro Alving fortfarande gick i gymnasiet och bodde hemma. Den 13 februari skriver hon bl.a.:

"Pappa träter för att jag inte vill läsa latin. Jag har ingen längtan efter att bli särskilt tongivande annat än i en liten krets och jag vill leva och inte bara läsa utdöda språk. Något sinne för vetenskap har jag inte alls. Hela mitt liv tror jag att jag kommer att sätta levande människor framför böcker." Den 16 februari är tonen mycket dyster:

"Vad ska jag göra med mig. Jag är aldrig riktigt glad, kan inte vara det helt enkelt, alltid sitter avundsjukan eller nånting bakom och gör mig ledsen. Jag vantrivs så gränslöst med allt, och det är så svårt att leva för allt annat tråkigt brukar jag slingra mig ifrån, men mitt eget liv kan jag ju inte fuska mig ifrån, inte ens skjuta upp." Hon klagar över att hon är "ful och tjock" och längtar efter att följa med de andra ut och jazza. "Jag skulle så gränslöst gärna vilja dansa och ha skojigt. Jag undrar om jag nånsin kommer att få det. Att sitta hemma, ful och klumpig och illa klädd och veta att alla andra är ute och har roligt - det är så man tappar lusten att leva. Och sånt kan man ju inte tala med någon om." (den 19 februari).

Storasyster Beat-Sofi var, som jag redan nämnt, tidigt på det klara med att hon skulle bli lärare som sin pappa. Vad Barbro skulle bli var däremot högst osäkert, vilket också gjorde fadern mycket bekymrad.

I dagboken grubblar hon (som väl de flesta tonåringar stundom gör) över sin egen identitet, men det tycks mig som om det var en speciell intensitet i Barbro Alvings grubbel. Den 21 
september skriver hon att hon är totalt misslyckad som flicka:

Hela min läggning, min håg, min själ är en pojkes, från det största till det minsta. Min heta lust att kämpa mig genom livet, att skapa själv, att göra något, min lust att beskydda människor som jag håller av, inte att beskyddas av dem, min lust att stå för mig själv, allt ända till min längtan att få ha manliga kläder, min totala brist på intresse för allt kvinnligt som hushåll och sömnad och småplock, städning och sådant.

Jag är såtillvida en pojke, jag hälsar som en pojke, har en pojkes gester, försöker utan att jag tänker på det, stryka mig över håret som en pojke, att hålla läpparna fast slutna, att sitta som en pojke. /.../ Gud fader har inte rättighet att göra mig sådan, att jag plågas av att inte vara någon riktig kvinna, att göra mig medveten om att jag är halvfärdig, inte pojke, inte flicka.

Varför har han givit mig längtan efter kärlek? Efter att som kvinna betyda något för en man, att leva i en luft av passioner, av kärlek och oändlig skönhet. /.../ Utåt tror nog alla att jag är fullkomligt nöjd med mig själv, att jag är så säker som jag ser ut, och det retar nog många. Om dom visste vilken darrande, skamsen, längtande, pinad, obotligt bakom människa jag är på områden där andra flickor rör sig med intuitiv säkerhet.

Barbro Alving tog studenten 1928 och började direkt som volontär på Stockholms Dagblad. Redaktör Ella Taube blev "min journalistiska mamma" skriver hon. Några månader senare tog hon steget över till Idun, blev redaktionssekreterare och filmrecensent och arbetade heltid till 1931, sporadiskt under ytterligare tre år, när hon skulle bedriva akademiska studier. Chefredaktören Eva Nyblom blev hennes vän för resten av livet. För Iduns räkning företog hon sin första utländska reportageresa, till Egypten. "Idun blev min katapult in i yrket och ut i livet" uttryckte hon själv tidningens betydelse för henne. I många år fortsatte Barbro Alving att skriva filmrecensioner för Idun. De akademiska studierna inleddes med ämnet franska och ett halvår i Frankrike, först i Paris, sedan mol allena i flera veckor i Bretagne. I Frankrike träffade hon en man som kom att inverka på hennes liv under en stor del av 30-talet. Studierna avslutade hon aldrig. Efter en halv fil.kand. behövde Dagens Nyheter en sommarvikarie, och där på DN förblev hon till 1959. I det längsta hade hon ingen egen bostad utan flyttade mellan olika vänner och bekanta eller bodde ibland hemma hos föräldrarna i Nockeby. Trots kappsäcksboendet började hon samla sina berömda blåa djur. Det första köpte hon i Paris 1931, när hon enligt egen terminologi var "kär och galen". Några av de goda vänner som betydde mycket för henne under de här åren är Karin Lamm, dotter till Martin Lamm, och Carl Gustaf Bernhard, blivande professor, samt Viveka Starfelt, jämnårig blivande författare.

Elin Wägner förtjänar ett särskilt kapitel i Barbro Alvings biografi. Elin Wägner hade varit redaktionssekreterare på Idun mellan åren 1907 och 1917 och kom fortfarande upp på tidningen då och då. Barbro Alving beskriver det första mötet med den äldre författaren så (året är 1935): "Jag var ökänd för min uppsluppna jargong och förmåga att slänga käft men blev nu helt plötsligt förstummad av att konfronteras med denna författarinna. Hennes böcker hade jag läst med stor respekt och beundran." Under hösten 1935 inleddes en stor kvinnoaktion för fred med Elin Wägner som drivande kraft. Aktionen kallade sig "Ned med vapnen". Barbro Alving ställde upp som ivrig medarbetare, hjälpte till att författa upprop i Tidevarvet, skriva manifest och brandtal och underlätta allt möjligt praktiskt arbete för Elin Wägner. Alla inblandade "har ohyggligt roligt" enligt Barbro Alvings egna ord. Aktionen led visserligen nederlag i NF men vänskapen mellan Elin Wägner och Barbro Alving bestod. I dagbok och brev ger Barbro Alving uttryck för sin stora beundran för Elin Wägner och hon hämtar styrka och ro vid besök i Småland på Lilla Björka. Första besöket där skildras i brev den 21 juli 1935 på följande sätt:

Hon har ett otroligt ställe, ett ljuvligt lågt långt rött hus mitt i en socken med rena smålandsbacken utanför och så hela huset fullt med all jordens böcker och 
vackra gamla möbler. Jag var fortfarande ganska förvirrad när jag kom, men tankarna ordnade sig lika självklart och obönhörligt som jordens gång bara av att jag var där.

Sitta i en länsstol med en Gandhibiografi i knät, ha Beethoven i radio och en småländsk skata i en björk vid verandatrappan och så ha henne vid skrivbordet bredvid och veta att hon skriver inte en rad som inte har sin förhistoria i hennes ansikte som jag älskar - du hör väl att jag måste komma över och prata.

Cilla Frankenhaeuser, finlandssvenska, lärde Barbro Alving känna samma år, 1935, och de brevväxlade flitigt under de närmaste fem åren, innan Cilla bosatte sig i Sverige och gifte sig med Eyvind Johnson.

Ännu en betydelsefull bekantskap gör Barbro Alving 1935, nämligen Karin Boye. De börjar umgås regelbundet och Karin Boye ber att Barbro Alving skall läsa och bedöma den nya diktsamling, som skall ges ut samma år. Diktsamlingens titel diskuteras också. Ett förslag är Martall men den slutliga titeln blir dock För trädets skull. Den 14 augusti skriver Barbro Alving i brev till Cilla Frankenhaeuser bl.a.:

Var hos Karin häromkvällen. Hon ska ha ut en ny diktsamling till hösten och bad mig läsa igenom den. Nu har jag just inga anlag att sitta i skaldens närvaro och häva ur mig omdömen på minuten och kan förresten aldrig fatta att en poet sitter och ser på varenda dikt som ett stycke vanligt arbete som kan ändras och härjas med av andra. Framför allt inte hennes dikter som går ner på botten av all ångest ibland. Men jag gjorde så gott jag kunde och där fanns underbara saker. Den här vill jag du ska tycka om,

varpå hon citerar "Ja visst gör det ont när knoppar brister". I september kommer diktsamlingen ut och Barbro Alving är med och firar detta mest hela natten.

Mitt i det hektiska fredsarbetet och det inte mindre hektiska arbetet på Dagens Nyheter kan Barbro Alving ge uttryck för djupt depressiva stämningar, som t.ex. den 12 september 1939:

Det gör så ont, så ont med denna idiotiska kärlek. I kväll är jag fulkomligt desperat. Varför kan man inte få vara i fred och vara olycklig? Varför kan man inte få vara ensam när man ändå är det?

Jag vill inte leva längre, om det ska vara på det här sättet. Jag vill inte vara den jag är. Jag vet inte vad jag ska göra med mig. Det är nån sorts ångest som gör att jag inte kan andas och jag ser ingen utväg åt något håll. Man ska bara orka och orka och orka hela livet. Just nu orkar jag inte orka någonting.

Den 28 oktober skriver hon till Cilla:

Nu sitter jag förhållandevis uppsnofsad för att gå på bankett i Stadshuset för Per Albin men det är en stund dit och den får du.

Det är nog ingen idé att jag försöker dölja att det är ganska bedrövligt med mig. Jag försöker rycka upp mig men det är som om jag inte orkar någonting. Hela dagarna består av en serie små nederlag. Jag kan inte sätta igenom det minsta beslut eller tänka en tankegång till slut. Det är någon sorts förlamning och jag vet inte vad jag ska göra med det. Nu har jag börjat gå bakgator igen av olust att möta folk. Det är ett säkert tecken på min speciella dementia. Jag ser fullkomligt förstörd ut. Allting syns tvärt utanpå mig.. Ibland går det bra en halv dag och jag tar i med saker med en viss kraft men så åker jag in i någon sorts dimma. Det känns som om det tog ett dygn innan jag får händerna på skrivmaskin. Inte ens Elin hjälper längre. Jag håller visst på att slarva bort det också. Jag tycker inte jag orkar vara henne till någon riktig hjälp./.../ I själva 
verket är det nog bara överansträngning av olika slag men nu kan jag ju inte komma ifrån. Jag har en känsla av att jag skulle behöva vara alldeles för mig själv en tid och tänka igenom hela det här året ordentligt och komma till något tankeresultat

En av de saker som tär på henne är uppenbarligen det komplicerade kärleksförhållandet till den man hon träffat i Frankrike. Relationen borde nu vara slut, hon är helt klar på det förnuftsmässigt, men "i stället åker jag in i rena saknadspaniken ibland och blir förbittrad ibland och alltihop är lika onödigt. Herregud ett sånt trassel man är."

Journalistlivet är stressigt med oregelbundna arbetstider och framför allt sena nätter. Alltför lätt kunde det också bli för mycket alkohol ute på olika krogar tillsammans med kolleger. Periodvis är Barbro Alving själv bekymrad över sitt oregelbundna liv och alltför vidlyftiga alkoholvanor. Arbetet inom fredsrörelsen störs också av allehanda konflikter, vilket ju är något paradoxalt.

Det bekymrar henne också att varken Vilhelm Moberg, Sten Selander, Tor Bonnier eller Sigfrid Siwertz gillar Karin Boyes diktsamling och hon oroar sig över de kommande recensionerna. Själv skall hon vara tredje opponent på Beth Hennings avhandling och gruvar sig kolossalt för detta akademiska spektakel. I Klarakvarteren rivs det och byggs nytt och Barbro Alving "har hand om hela Nobelfirandet. Och jag är komplett betagen i Curie." "Jag var alltså på stora Nobelfesten igår och jag måste erkänna att den fyller mig helt hur barnsligt det än anses vara ur journalistisk synpunkt. Dom får förresten säga vad dom vill, men det var tack vare min gripenhet inför Curie som jag skrev ett av bladets bättre reportage. Vilket dom erkänner och därför är jag på ett sagolikt lynne idag. Jag jobbade som en besatt i natt och att sen vakna och se att man har skrivit en hygglig sak det räcker."

Jag kan inte låta bli att citera ett litet lovtal över Uppsala från den 26 oktober 1935:

I himlen har jag nästan varit idag, för jag har varit i Uppsala. Det är den enda stad på jorden som jag faktiskt älskar. Jag skulle vilja klappa den på kinden för den är så förgrymmat söt. Det var svinkallt och hela Uppsalaslätten blåste på mig men att streta runt Svandammen i blåst är det tjusigaste jag vet. Jag var där för att jaga en abessinsk sjuksköterska på Akademiska och bara för att göra mig glad var hon söt hon också. Min känsla för den stan är egentligen rolig för jag känner ju inga människor där mer och har ju inte i egentlig mening upplevt någonting där mer än 10 år som jag knappast minns, men jag blir så himla glad bara jag kommer av tåget och att gå en marskväll och driva under läroverkskastanjerna innebär den tjusigaste form av dunkel oro jag vet.

Senare hälften av trettitalet präglas också av att Barbro Alvings mor Fanny Alving gled allt längre in i mentalsjukdom med förföljelseidéer och självmordsförsök. I det längsta försökte man behålla henne i hemmet i Nockeby men fadern och de två döttrarna måste till sist inse att det inte var möjligt utan förde henne till Beckomberga. Mitt i detta personliga kaos fortsatte fredsarbetet, fastän det föreföll alltmer omöjligt med Hitler och Mussolini skramlande med vapnen och det spanska inbördeskrigets utbrott 1936. Barbro Alving drev igenom att hon fick åka dit som krigsreporter, delvis med livet som insats, och blev på kuppen berömd och blev Bang med hela svenska folket och använde första halvan av nästa år till att resa runt och hålla föredrag om sina upplevelser. Det är nu, 1936, somhon lade sig till med sin berömda basker som huvudbonad i ur och skur. Dessförinnan hade hon under sommaren gjort bejublade reportage från Olympiaden i Berlin. "Tyck inte att jag skryter men jag måste ju säga som det är. Kapten var för första och enda gången artig och jag fick 300 kronor i gratifikation. Så nu är man Sveriges styvaste journalist, piddelipej, komiskt det är vad det är. Men du fattar ju att jag är glad, det här klarar hela karriären."

Hon är också klarsynt när det gäller den egna alkoholproblematiken och inser att hon behöver läkarhjälp. Den 16 mars 1936 skriver hon: 
/.../ jag har idag fattat gräsligt mycket mod och ringt till Dea och bett att få konsultera henne. Om min tilltagande alkoholisering, det sade jag inte men hon får väl veta på fredag när jag ska dit. Jag märker att jag faktiskt inte kan klara saken själv /.../Jag tror det är det värsta med den här sjukan att det är så, när lusten sätter till så tappar man kontakten med sig själv. Och jag är inne i ett fullkomligt hjälplöshetsskede sedan ganska länge.

Hon inser att det är en sjukdom och "jag är inte speciellt svag eller dålig på annat, men spriten är som feber." Beroendet av Elin Wägners vänskap och närhet accentueras:

/.../nu gör det ont när hon reser. Jag behöver henne så förtvivlat väl och har redan kommit på mig några gånger med att längta vilt efter henne. Det liksom vågade jag aldrig förr och det är som sagt lätt skrämmande, om det är något jag med skäl är rädd för så är det saknad av en människa. Har liksom haft nog av det. Dessutom drunknar jag snart i svenska Kyrkans psalmbok. Jag har haft ett hundra arga prelater i telefon för att jag satte journalistiska rubriker på enquèten, inte deras eviga å ena sidan - å andra sidan. För att vara Kristi brudar grälar de förvånansvärt bra.

Utskickad till NF i Genève vantrivs hon p.g.a. den absoluta händelselösheten. I brev skriver hon den 31 oktober 1936 bl.a.:

Jag duger inte till någonting annat än att journalista, blir omöjlig när jag inte får ägna mig precis åt det. Inte flänga runt och skaffa s.k. nyheter, det är en helt annan sorts journalistik, men vara där det är något och ge ramen, miljön, folket, händelserna, kalla det vad du vill. Hade jag varit fri nu skulle jag ha rest till Bologna och tittat på Mussolini i förra veckan. /.../ Jaha, där sitter man och även mitt i det kanske man känner tusen gånger att man inte duger och allt det där, men det må vara hänt, bara man får vara med./.../ Skriva om kvinnosak, om fredsjobb, gärna det, men sitta fast i det kan jag inte, så tokigt det än låter.

År 1937 upptas av reportageresor till Berlin och till Spanien och på det personliga planet av två viktiga ting. Det ena är moderns sjukdom. Ibland kan hon vara hemma eller på Stallarholmen. Den 12 september skriver Barbro Alving att hon varit och besökt modern där, "det är som det har varit de senaste månaderna, inte särskilt svårt men jag blir så förtvivlat deprimerad ändå, för som det var förr blir det ju aldrig mer och hon är alltid alltid ledsen." Det andra, än mer genomgripande, är att Barbro Alving väntar barn med en av DN:s tecknare, Birger Lundquist. Dessvärre är han gift, och när det positiva beskedet kommer om graviditeten finns han på onåbara platser utomlands och får inte vetskap om saken förrän vid hemkomsten i december. Barbro Alving beslutar sig för att föda barnet och ensam ta hand om det, om det skulle behövas. Den 31 augusti skriver hon till Cilla:

Glad är jag inte ännu, men det kommer nog. Kan inte vara det nu av det enkla skälet att jag är så förtvivlat trött jämt så det är inte sant. /.../ Lilla söta Cilla, du fattar väl att jag behöver dig och alla mina vänner bättre än någonsin nu, att inte tala om i framtiden. Värsta tiden blir innan ungen är född, sen blir det väl så skojigt så det går av bara farten. Ekonomiskt är det också ett problem, att inte tala om vad stackars gamle lektorn ska säga. Men längst ned i själen vill han nog ha sig ett barnbarn, legalt eller inte. Och på Birger litar jag som på gud fader.

Först den 13 november skriver hon till sin syster och meddelar nyheten. Hon säger sig bara ha mötts av respekt på tidningen, och vad skandalen beträffar så väntar sig folk bara vad som helst av henne. Pionjär är hon också, anser hon.

De flesta har nog i grunden den inställningen att kan man bara sköta vad man ställer till så är det ens ensak. Framför allt om man går omkring småleende 
och frank och verkar som om det vore det naturligaste i världen. Den heter tills vidare lilla Ruffa, det är Cilla som har döpt den, men jag lovar att det skall bli ändring när jag vet vilken sort det är.

Hon skriver också senare att hennes emancipation sträcker sig så långt som att vilja ha Ruffa och klara upp det och kalla sig fröken, om så är, och strunta i vad folk säger, men inte till att utesluta barnafadern. Han har rätt att bestämma ett och annat han också och hon respekterar hans faderskap.

De första månaderna av år 1938 går åt till att skaffa en bostad med "två stora soliga rum för mig och ett avskilt skrikrum för Ruffa och ett lantligt badrum med träribbor och rum för plask." 2400 kr per år kostar härligheten. Ekonomien är det stora orosmomentet. Samtidigt anser hon det tydligen för självklart att barnet skall ha en barnsköterska, som något år senare byts ut mot ett hembiträde! Ruffa föddes den 25 februari och allt gick väl. Men något äktenskap blir det inte. Birger kan inte besluta sig för att skiljas. Dessutom blir det ganska snart uppenbart att han är svårt sjuk och knappast heller kommer att kunna bidra med några pengar. Återstår alltså för Barbro Alving att nästan omgående kasta sig in i arbetet igen. Hon trivs förstås med att det rör sig omkring henne men klagar över att lillan känner sig mer hemma med barnsköterskan än med henne. Radioreportage är en ny genre som Barbro Alving snart blir en mästare i. Hon börjar också inse att hennes styrka som journalist ligger i utlandsreportage.

Jag vill inte påstå att man har för litet att göra i hemmaredaktionen för nog gnor jag, men det passar ganska dåligt för mig numera. Jag har en känsla av att jag växt ifrån det mesta, vilket må vara ett malligt misstag, men känns det så så känns det. Och hela Ruffas framtid hänger på att jag gör karriär eller vad det skall kallas och märks och syns och blir något som dom vill betala högt. Och det kan man som pressen här är just nu knappast göra annat än som utrikesflygande. Så jag vill ut igen så fort det bara finns en möjlighet. (brev till Cilla 30 maj 1938).

På midsommardagen 1938 beskriver hon bl.a. för Cilla sina insatser i samband med kungajubileet (Gustaf V 80 år) och försvarar sina lama insatser beträffande fredsarbetet med att 1) hon har träffat Karen Blixen och inte hunnit något annat, 2) är överansträngd i största allmänhet, 3) Ruffa, 4) den komplicerade världssituationen, 5) brist på kraft så att hon bara inte orkar just nu. Däremot får hon i uppdrag att fara till världsutställningen i New York på försommaren 1939 och återvänder med utmärkta reportage, som vanligt, glad och nöjd att ha sitt barn, en riktig kärlek och en utmärkt hälsa, "Har magrat jämnt nio kilo och är torr som överståthållare Nothins middagstal." (!!)

Så bryter kriget ut den 1 september. Det enda hon vill är att få komma ut, en sorts reporternervositet, som hon kallar det. Det är viktigt att alla gör sin plikt och sin insats hemma också, visar lojalitet, och "jag försöker hårt hålla mig till att bara råarbeta för att bli ekonomiskt fri. Jag räknar ören och veckor med samma intensitet. Och att under tiden visa lojalitet och god vilja i arbetet här." Hon försöker analysera sin otålighet men det går inte så värst bra. "Det enda jag märker när jag stillnar för att känna efter är att äventyrslusten eller rättare sagt ångesten att det finns saker, som jag inte får uppleva och som därtill andra får uppleva, dominerar. Och den är nog en ytterst viktig del av en reporters utrustning skulle jag tro."

Den 7 september skriver hon i dagboken:

Skolkat från tidningen, behövde samla mig en dag. Detta med krigskorrespondenten hemma blir snart en fix idé. Plågan ligger ständigt under, i två skikt. Dels mörkt Paris, mörkt London, hårt jobb, atmosfär, krig vid fronten. Dels Bang borta ur DN, hack i karriär, obotlig skada. Är det väl inte, men svårt hålla tankarna borta. 
Dagen därpå skriver hon bl.a.:

Jag är nog i schizofrenaste laget, idag har jag varit på ett utmärkt lynne trots en jädra huvudvärk. Det lilla jag gör går villigt och glatt, chanserna att komma loss i mars ter sig också trevligare nu. Blir snart annars som gubben i Uppsala som skrev reseskildringar från Persien och aldrig kom längre än till Södertälje.

Det dröjde inte ända till mars, innan hon kom i väg ut. Redan den 30 november reste hon över till Finland och vinterkriget och blev kvar till vapenstilleståndet 13 mars 1940, och sedan bar det av till Norge och Trondheimfronten i april. Varken dagbok eller brev skrevs under dessa månader. Det fanns varken tid eller möjligheter till det. Med krigsreportagen från Finland och Norge befäste Bang sin ställning som "Sveriges främsta reporter", och hennes artiklar översattes till engelska och gjorde stor succé både i England och Amerika. Hon hade brinnande gärna velat komma över till England under Blitzen vintern och våren 1941. Tidningen ville inte släppa i väg henne, men hon tog resolut tjänstledigt och for med livet som insats via Finland och i konvoj till USA. Där blev det emellertid stopp. Hon vistades i USA (Washington alternativt New York) mesta tiden, gjorde mängder av reportage och intervjuer, bl.a .med kronprinsessan Märta av Norge, träffade Gunnar Myrdal, Ingrid Bergman, Sigrid Undset och många andra, men till England gick det inte att komma. Med nätt nöd tog hon sig hem med en finsk båt, den sista som avseglade från USA sommaren 1941. Under alla dessa månader hade hon slitits mellan det ansvar hon kände för att rapportera de stora världshändelserna och göra sin insats, äventyrslystnaden, medvetenheten om att hon hade en karriär och en prestige att försvara å ena sidan och den ångestladdade längtan efter den lilla dottern Ruffa, som hon i brev hem skriver att hon inte ens vågar tänka på, och efter Loyse Sjöcrona, som från och med hösten 1940 delade bostad med Barbro Alving och Ruffa. (Loyse kallades Viran i kåserierna).

Klyvnaden i lojaliteter tär så mycket på henne att hon får ett sammanbrott och tidvis har svårt för att skriva. Hon får också mitt i det hektiska livet i USA litet tid över för eftertanke och skriver bl.a. i brev till Loyse Sjöcrona i mars 1941:

Längst ner på djupet rör mig inte saken så värst, jag har alltid varit en aning likgiltig för jag tror inte det här är demokratiens kamp mot dess motsats. Jag tror som Wägner tror, att det är en felbyggd civilisation som fräter sönder sig själv, en karlcivilisation, och att vad som borde göras inte är att sno omkring och kommentera karldestruktiva ting utan gå på fruntimmerslinjen och göra om allting från början med respekt för livet. /----/ Loyse, hur många gånger lever man? En, minsann. Vad händer under de tio åren närmast efter sen man puttats i graven? Man blir så glömd som aldrig det, en tid minns några en kanske "som hon som var en sån duktig journalist", sen är det också borta. Men Ruffa finns kvar och hennes barn /.../ och det är vad hon minns av mig och vad hon fått av mig under våra år tillsammans som är det enda viktiga. Jag kan nog fan vara duktig ändå, men jag vill få tänka litet också. Och jag vill få vara människa, inte bara yrkesmänniska.

Frånsett dessa resor satt hon fast hemma i Stockholm och det svenska vardagsslitet med mörkläggningsgardiner och ransoneringskort. "Jag kände mig instängd i Sverige under krigsåren," skrev hon långt senare. Utrikeskorrespondent var vad hon ville vara men hon kom inte ut, och det tog på nerverna. Samtidigt slet hon hårt på hemmaplan, inte bara på DN utan hon extraknäckte i Idun och andra veckotidningar, översatte och bearbetade åt bokförlag, gjorde radioprogram och höll föredrag, bl.a. om Finlands sak, kåserade regelbundet i VJ varje vecka från 1942, skrev filmmanus, författade festtal och sketcher. Man kan fråga sig hur hon orkade. Det gjorde hon, utåt, men inte inåt. Hon plågades av enorma prestationskrav på sig själv, tvivel på sig själv och sin förmåga. Hon fick aldrig ro att skriva något riktigt, en bok t.ex. eller att fördjupa sig. Hon ville både stå i händelsernas centrum och göra karriär och samtidigt vara en bra mamma åt Ruffa, ha lugna stunder med Elin Wägner och få lugn i sin själ. Ekonomien var som vanligt prekär: ensamstående mor med ett barn att försörja, våning och barnsköterska (senare hembiträde) att betala lön till, 
sommarnöje i hyrda stugor i skärgården för barnets skull etc. Kort sagt, hon "syndadepå nåden" som hon själv kallade det, arbetade för hårt, levde för hårt (även med alkohol) och slösade med sitt liv och sina resurser. Skyddsnätet var dock familjen och de närmaste vännerna, samt först och sist Ruffa. Med Loyse Sjöcrona hade ändå en viss trygghet kommit in i Bangs liv. Hon visste att hon kunde lämna Ruffa i hennes vård med fullkomlig trygghet. Ruffa Alving-Olin skriver i sin kommentar till moderna dagbok och brev från 40talet att man kunde få för sig att Bangs liv ständigt var fyllt av kriser och krångel. Så var det inte, men dagens roligheter skrev hon sällan ner.

Jag minns min barndom som ljus och glad. "Sällan har det skrattats så mycket åt så litet av så få", sade Barbro om sin uppväxt i det alvingska hemmet. Jag kan säga detsamma om min. Vi hade roligt! När mamma var hemma ...

När kriget tog slut, satt Barbro Alving fortfarande kvar hemma på redaktionen och först i juli kom hon i väg utomlands. Hon följde då Gustaf V under hans besök hos de danska kungliga släktingarna. På hösten bevakade hon Quislingrättegången i Oslo och år 1946 gjorde hon två stora reportageresor genom "efterkrigsverklighetens Tyskland" och ett reportage om hur Danmark firade befrielsen. Mest satt hon hemma och slet, med redaktionsjobbet, med filmrecensioner och annat extraknäck. Pengar behövdes mer än någonsin, eftersom hon funnit och köpt ett drömställe i Roslagen, "Torpet" 1945. Glädjande händelser var att Elin Wägner kom in i Svenska Akademien 1944, Herbert Tingsten blev chef på DN 1946 och samma år, 1946 kom hennes första samlingsvolym kåserier ut, kåserier under signaturen "Käringen mot strömmen". Därefter kom det en kåserisamling i stort sett varje år.

Av dagboksanteckningar från åren 1945 och 1946 och även av brev till främst Elin Wägner framgår att Barbro Alving hade svåra perioder av depressioner, av alkoholbegär och av misströstan om sin egen förmåga. I dagboken 19 februari 1946 står det t.ex.:

Mina nerver totalt i olag, kan inte få någon fast punkt någonstans. Grubblar över ställning, i yrket, vad folk tänker om mig, hur det ska gå, hur jag ska orka, om jag ska duga, kan inte hålla fast Torpet heller som lösning och trygghet. Är bara en enda djup längtan efter vila, efter att slippa slava ihop pengar. Känner mig förföljd av tiden var minut, hur jag ska hinna allt jag måste ta på mig. Att ett liv kan bli så fel. Världshändelser och skit hamrar på en också, jag kan liksom inte hålla något från livet, varken atomeländet eller förljugen filmreklam.

Det gäller att hålla masken, trots magkatarr och plågsamma ansiktssmärtor. I brev till Elin Wägner skriver hon den 15 augusti 1946 om intryck från reportageresa till det sönderbombade Tyskland och Frankrike:

Mitt privatpersonliga intryck av resan var att ju mer man ser av Europa, och inte bara Tyskland utan Frankrike också, dess starkare blir ens känsla att man någonstans på denna jord måste ha en undanskymd plätt för sig själv, en som just ingen kan ha lust att komma åt för den är inte åkerjord eller något annat användbart. Det är den - fortfarande privatpersonligt - värsta upplevelsen, känslan av absolut osäkerhet, av att vad som helst kan hända vem som helst, att katastrofer ligger och lurar i alla hörn.

Jag tror det är mest de trasiga storstäderna och folks kraftlösa sätt att tala och tänka som gör det - varken dessa hus eller dessa människor visste från början vad som skulle gå över dem eller var ämnade till det. Otrygghet, otrygghet överallt och den smittar förfärligt. Så jag välsignar mitt lilla torp.

Under den här tiden skriver Barbro Alving också manus till filmer, bl.a. tillÅsa-Hanna som hon dessutom bearbetar för radioteatern. På DN har Herbert Tingsten tillträtt som chefredaktör, något som hon hälsar med glädje. 
På vårvintern 1947 kom Barbro Alving i väg på en resa jorden runt och beskrev det som att "det känns som att komma upp från botten av en brunn." I sin journalistiska memoarbok skriver hon om denna resa, som inte alls blev som hon tänkt sig:

Tokigare än denna jordenruntfärd har aldrig en resa planerats, och det var helt mitt eget verk. Resan skulle beröra 13 länder, den gick över 8 hav, omfattande 4 fjärrbåtslinjer, 17 flyglinjer, 29 hotell, frånräknat hyddor, samt 11 valutor som man skulle hålla räkning på.

Dessutom var det tropiskt hett och i Indonesien pågick krig. Alltsammans skulle avverkas på sex månader. Så blev det nu inte. Allehanda komplikationer tillstötte, bl.a. också en depressionsperiod med ty åtföljande svårighet att skriva. Hon var också med om ett allvarligt flygtillbud, vilket orsakade en djup depression och flygskräck. Först i mitten på mars 1948 efter nästan ett år, kom hon tillbaka till Sverige igen. Trots alla strapatser resulterade resan i 40 artiklar i DN och hon förblev "Sveriges främsta reporter" även om hon alltjämt brottades med svårartade tvivel på sig själv och sin egen förmåga. Några citat kan åskådliggöra detta.

Den 28 oktober skriver hon från Shanghai till redaktionschef Sten Hedman på DN att:

/.../ min prestationsångest numera antagit oregerligt format. Förmodligen bottnar den i egocentricitet, vilken i sin tur förmodligen bottnar i någon sorts divanatur, men det är nu en bisak. Huvudsaken är att jag känner förväntningarna hemma på vad jag skall komma med som en ren börda, tillräckligt tung för att platta ner mig till skrivskräck. Detta har för övrigt pågått i några år, men om jag fattat telegrammet rätt så anses det numera att jag därigenom satt DN i klistret - med all reklam ni gjort för mig - och då är det på tiden att jag betänker läget och tar konsekvenserna. Du skall veta att redan från allra första början på resan, Indienartiklarna, som ni enligt telegrafiska budskap tydligen var nöjda med och ansåg kom när de skulle komma, var jag själv oavbrutet halvförtvivlad för att jag inte hann, inte fick i väg fort nog. Och det har sedan bara accelererats. Jag har skrivit ett s.k. lustigt kåseri om uppskjutardjävulen en gång, i realiteten är det inte så lustigt.

Hon talar i brevet också om sitt grundlighetskomplex, vilket ju också är opraktiskt för en dagstidningsjournalist, och erbjuder sig att säga upp sig. Hedman lugnade henne emellertid.

Det var inte heller alldeles enkelt att komma hem till vardagliga förhållanden efter så lång tid. I brev skriver hon i april 1948 bl.a.: "Djupare analyser på hur det känns att komma hem efter detta år är jag inte mogen för än. Närmast kluvet skulle jag vilja säga. Går inte att förena två såna verkligheter, ibland är jag själsligen här, ibland där."

I januari 1949 dog Elin Wägner, något som tog Barbro Alving mycket hårt. Tydligare än tidigare börjar det också komma fram i dagboken behov av tystnad och koncentration och grubbel över livets mening. Den 18 maj 1949 står det i dagboken:

Skrev två deckarrecensioner före posten. Svårt komma igång sen, drar mig för att läsa mina egna anteckningar och råkar ibland i sådant missmod. Borde väl ha slafsat ur mig en ögonblicksbok förra året, har inte stoff och djup till mer. Säger mig nästa minut att sluta grubbla ocharbeta i stället./.../ egendomligt eller inte egendomligt att alla böcker handlar om Arnolds-temat: Meditation, ge din själ en chans att finslipas, var tyst inom dig, och lugn. Tänkte tre ting: Det ena att detta med tystnaden är rätt, det andra att min ruelse för det förgångna också är verklighetsflykt och bör överges, det tredje att jag ändå aldrig, ej heller nu, betvivlar meningen med en själens klarhet och finslipning.

Redan den 29 januari, bara tre veckor efter Elin Wägners död, hade hon en upplevelse, 
som jag inte vågar ta på än. Det är, tror jag, /.../ att frön måste få ha det mörkt och tyst, man ska inte tala om allting. När jag satt i bussen, $i$ vintereftermiddagsskymning, råkade jag se upp mot himlen. Den var mjölkig men på något sätt hög. Och jag fick en så stark känsla att Elin finns, någonstans bakom denna himmel. Hon är inte död, hon har kommit hem till någon annanstans och därifrån följer hon oss. Det finns ingenting som är död. Jag fick en svindlande känsla att det kanske blir Elin som lär mig till Gud, men det vågar jag inte röra vid än. Blev bara så lugn, och det lugnet satt i hela kvällen. Försökte be när jag lagt mig, det gick väl inte så värst, men det gör inget. Misstron mot mig själv har liksom släppt, man får göra så gott man kan./.../ Jag vet inte vad det är som hänt, men kanske är det något.

I slutet av september skriver hon i dagboken:

Jag är som ett träd vars rötter inte når ner till källorna. Ibland vibrerar det inför ting hon säger (Emilia Fogelklou), mest om det tysta arbetet i en själ, men det når mig inte ännu. Vad jag har kvar är väl ett: tron på andliga övningar. Gud, vad jag längtar efter någon att tala med. Och efter kväkarnas Gud.

Hon är upptagen en stor del av hösten med att resa runt och hålla föredrag om Väckarklocka och upplever samtidigt att människor berörs och att de får förtroende för henne och kommer för att ventilera personliga problem. Den 16 december har hon besökt Harry Martinson, som skall efterträda Elin Wägner i Svenska Akademien. Hon har fått läsa Harry Martinsons tal över Elin Wägner och är oerhört upprörd, därför att hon tyckeratt Martinson gjort Elin Wägner mindre än vad hon var och hela tiden talar om hennes "nederlag". Hon avslutar dagens antecknar i dagboken: "Att Elin slipper vara med om detta det enda bra. Jag vet nu att jag behövs. Och att min kärlek till henne bär."

"Det enda människan tror på är handling" skrev Barbro Alving i dagboken i januari 1952, och den sentensen sätter hennes dotter Ruffa som rubrik över Bangs 50tal. "Åren då hon finner sig själv, sin väg. Och mognar fram till handling efter sin övertygelse", som Ruffa skriver i förordet till den fjärde delen av Bangs brev och dagboksanteckningar Personligt.

Det finns stora luckor i dagboken, vilket delvis förklaras av ett högt arbetstempo, delvis av att denna dagbok, som hon själv skriver är så nödvändig för henne för att få klarhet i sina tankar och perspektiv på sin utveckling, samtidigt kan bli en belastning, i synnerhet eftersom den tar energi från arbetet på biografien över Elin Wägner. Är det något som verkligen genomsyrar hela detta årtionde så är det hennes vanmakt inför den uppgiften. Hon reser land och rike runt och samlar material, brev, intervjuer etc. Hon tar t.o.m. periodvis tjänstledigt för att få den nödvändiga koncentrationen - med än trassligare ekonomi som följd och därav följande nödvändighet att extraknäcka som översättare, biorecensent, deckarrecensent etc. Därtill kom kraven att skriva en "Käring" i veckan, något som periodvis tycks ha varit en hart när övermäktig uppgift. Dessutom har hon initierat ett årligt Wägnerstipendium för kvinnohistorisk forskning och får uppenbarligen dra det tyngsta lasset i det löpande stipendiearbetet. Fredsarbetet i Elin Wägners anda fortsätter oförtrutet med föredrag utifrån Väckarklocka, med kampartiklar i Hertha, Fred och Frihet och andra tidningar, med kampanjer för ett alternativt, icke-väpnat försvar tillsammans med bl.a. Sara Lidman och Per Anders Fogelström. Dessutom är hon en av initiativtagarna till AMSA (Aktionsgruppen Mot svensk Atombomb, bildad 1958). Kvinnosaken ligger henne fortfarande varmt om hjärtat och hon engagerar sig som journalist i debatten om kvinnliga präster. Som redan nämnts tidigare tog hon konsekvenserna av sin radikalpacifism och gick i fängelse för sin vägran att delta i civilförsvaret. Det tycks dock som om fängelsemånaden snarast var en ganska välbehövlig paus i ett alltför hektiskt liv med möjlighet till samling och egna studier. Hon säger också upp sig från DN eftersom hon inte kan solidarisera sig med ledningens (främst kanske Tingstens) positiva attityd till atomvapen. Denna oräddhet och detta civilkurage är en av de egenskaper som framträder tydligast om man skulle karakterisera Barbro Alving. Humorn, slagfärdigheten och satiren är förstås andra drag. Men det som hon dolde för alla utom för 
de närmaste var ångesten, prestationsvåndan, skrivkrampen, depressionerna, alkoholberoendet, som periodvis tycks ha varit plågsamt stort. Att hon mitt i dessa svårigheter och denna vånda kunde prestera så mycket är beundransvärt. Men biografien om Elin Wägner blev henne övermäktig. År 1967, efter 18 års kamp, överlämnade hon allt sitt material till Erik Hjalmar Linder och Ulla Isaksson.

Jag skall citera ur dagboken eller ur brev, några citat per år från femtitalet. Den 19 april 1950 skriver hon bl.a.:

Satt och tänkte i ensamheten på eftermiddagen. Försökte komma till en bas, en gemensam nämnare för min situation med arbetet. Kände ett par ögonblick svagt riktiga ting snudda vid mig. Tänkte ungefär så här: nämnaren för allt olika som jag har för händer måste vara min kärlek till Elin. I kraft av den får jag inte misströsta, inte skjuta upp, inte känna meningen glida mig ur händerna med alla olika sorter, människor, uppdrag, ärenden. Allting måste skötas, och det prompt. Plotter får inte dyka upp före henne i arbetet och inte i själen. Det är min enda väg. - Jag tror $\mathrm{i}$ all enkelhet att dagliga små andliga övningar är det enda jag kan göra för att öppna alla kanaler, ta emot henne igen. Komma därhän att glädjen över att hon levat är mer givande än att försöka aktualisera sorgen över att hon är död. /.../ Just den stunden var jag full av hopp. Måste försöka behålla det.

Den 30 juli 1950 skriver hon, att hon är bättre i gång än på länge. Hon har, skriver hon, haft en känsla av att

allt gaddat ihop sig för att försvåra nalkandet till ett personligt Gudsbegrepp. Intellektualismen reser till den grad borst. Har varit två direkt hämmande ting, det ena har jag tappat bort, det andra var bulletinen med karsk polemik mot det ensidigt fadern-sonen-baserade Gudsbegreppet och eliminerandet av den kvinnliga principen. Knäpper bara mina händer för att tacka någon, något, för att vi i mitt hus har det så bra.

Dagen därpå skriver hon att den som följt hennes bana med spriten i dagböcker etc.

måste få en trist bild av en lindrigt eller i varje fall på mindre vanligt och skvatt gåtfullt sätt alkoholsjuk. På mitt nuvarande stadium - kan med lätthet låta bli - kan jag fastställa följande: det är tydligen skuldkomplexet som är det väsentliga. Dricker jag en droppe får jag olustkänslor och tvångstanken att det gäller att supa undan för att sluta nästa dag: aldrig mer. Detta kolliderar med min djupa lust att kunna vara som andra normala sällskapsmänniskor, vilket i och för sig ligger inom räckhåll.

I september 1951 noterar hon att Loyse tvivlar på hennes förmåga att fullborda ett större arbete. Asienboken blev ju aldrig färdig. "Det tog. Det är inget vidare värst med mig." En månad senare, den 14 oktober, beslutar hon sig för att skjuta på arbetet med Wägnerbiografien under resten av hösten. Hon inser att det inte går att kombinera detta arbete med det vanliga journalistiska arbetet, och de närmaste veckorna skall hon först turnera i Norrland och sedan i England fram till julen.

Den 9 januari 1952 går hon upp till Oscars pastorsexpedition för att anmäla sitt utträde ur Svenska kyrkan. Någon motivering anges inte i dagboken. Resten av våren präglas av Birger Lundquists sjukdom och död och att få Ruffa igenom sorgen efter en far, som hon fått lära känna alldeles för litet.

Den 6 april skriver hon bl.a. att hon upplevt en våg av klarhet och att hon i ord försöker uttrycka

den erfarenhet Birgers död givit mig: kärleken förklarar allt. Det är kärleken 
som gör att man försonar sig med döden, d.v.s. ordet försona är fel i mitt fall, men jag vet inget annat. Kärleken är verkligheten, i vars ljus allt blir enkelt, den stora enkelheten. Det finns ingen motsättning mellan liv och död i kärlekens ljus. Birger har levat och älskat och älskats och är död, jag lever och älskar och blir älskad och skall dö - det är bara en tempusförskjutning. Allt hänger organiskt och vackert ihop: liv-kärlek-död. I den stunden /.../ skymtade jag den högre verkligheten, den som gör en orädd och osårbar: Men störst av allt är kärleken. /---/ och kom på att en nyckel till felet i mitt väsen är /.../ att jag är stadd i utveckling till fullvuxenhet. Det tror jag även när jag känner det som mörkast,/.../ felet med mig är att jag till synes kämpar för ting, Elins ting, men jag lägger inte lidelse i att det skall lyckas utan skjuter undan och "gör så gott jag kan".

Dottern Ruffa konfirmeras den sommaren, 1952. Barbro Alving har som alltid alldeles för mycket omkring sig och får svårartad käkkramp av stressen. Den 31 juli 1952 skriver hon:

Käkkrampen något bättre under dagen, ibland har jag korta moment av inre lugn men kan inte hålla fast dem. Småningom måste jag ju rulla upp hela problemkomplexet med min känsla av tomhet och längtan efter andlig verklighet. Hörde morgonandakten, gav i varje fall en känsla av lugn förvissning att något finns fast jag nu inte orkar nå det.

Den 5 september 1953:

Söker, söker. Söker lågan, min låga. Förrän jag får den i bröstet blir det inte mening och mod och lugn. Låg och tänkte på Elin i morse, sökte åt det hållet. Kände: en värld där våra barn uppfostras till att tro att organiserat och legaliserat brodermord är tillåtligt måste det göras något åt. Man får inte förvirras av att det till synes går framåt och kvinnorna inlemmas och ingen annan kraft behöver lösgöras. Kändes som fast mark där. Där borde klarhetens väg ligga. Och det som kan göra att jag kan slåss mot otillräcklighetskaos med glädjen som vapen. Något lossnade litet under detta, tror jag.

Den 14 september 1953 skriver hon:

Man skapar sig inte en låga och tro med att fundera. Jag står inför en klar plikt: Elins kvarblivande i människovärlden och möjlighet att påverka beror till en del på mig. Det är oerhört - ett helt liv och vad det ville. Konsekvensen är egentligen så enkel: jag får ställa åt sidan mig och mitt sökande och göra detta. Att fortsätta söka klarhet i den här situationen är att fly in i sökandet tror jag. /.../ Jag måste sätta igång med arbetet och se vad som kommer därav även för mitt sökande. Varför skyggar jag där? Jag har ju inte prövat hur det känns att dyka in i det som en förstoring av den absorption jag känner när jag skriver en artikel. Och det är ändå det lugnaste jag har, när det känns att det bär, då grubblar jag inte på sjutusen saker.

En av orsakerna till hennes svårighet att komma igång på allvar med biografien är uppenbarligen hennes djupa tvivel på att hon duger till det. Om hennes bildning och begåvning räcker, och om inte någon annan skulle göra det mycket bättre.

Nu har jag väl i Guds namn kommit till botten i detta. Och härmed får jag sluta med allt grubblande och tänkande och reducera situationen till: skyldighet. Jag får sluta analysera och istället ge ämnet en chans att absorbera mig. Man får helt enkelt strunta i sig själv och ta det hela litet leende.

Året 1954 är förvånansvärt blankt i dagboken med bara några sporadiska anteckningar. Den 17 januari 1955 skriver hon att hon "är uppryckt efter en svår downperiod, men med förvånansvärt hygglig fasad utåt." 
Den 3 juni 1955 står det lakoniskt: "Mamma dog igår natt. Orkar inte skriva dagbok nu."

Fadern blir mycket ensam och glider successivt in i allt större glömska och frånvaro mentalt. Den 12 februari 1956 skriver hon i dagboken om ett besök hos fadern i Nockeby, att hans huvud är allvarligt mycket sämre och att han inte kan hålla fast i minnet att hans hustru är död. "Han vaknar varje morgon ovetande och måste igenom pärsen igen. Samtidigt är han klar nog att undra över att hans hjärna är så försliten så han inte kan hålla fast detta i sitt medvetande."

Barbro Alving har via Emilia Fogelklou närmat sig kväkarna och skriver om detta den 14 februari:

Tanke vid läsning av kväkartidningen en av dessa kvällar: det andra tycker är märkvärdigt hos mig tycker jag själv inte alls är märkvärdigt. Jag vill annat och skulle se det som märkvärdigt: stillhet, tillit, inspiration, vision, kraft. Att jag inte kan bli kväkare får jag finna mig i, eget fel. Men jag kan göra andra glädje.

I september 1956 hyr hon en stuga på Tjörn för att få litet ro att tänka och arbeta koncentrerat. Den 13 september står det bl.a. i dagboken:

Satt och tänkte litet, så där. Nyckelord: min själ är svulten. Så är det, så litet har illförts den på så länge - jag märker det bäst på att allt andligt, från religiösa ting till centrallyrik, så klart och direkt angår mig och verkar skrivet för mig personligen. Har en känsla av att min själ måste matas som en fågelunge framöver. /.../ Jag måste godta att jag är en egocentriker med oroligt sinne, den evigt malande lilla orons människa. Godta att jag inte kan koppla av. /.../ Inte ha skuldkänslor för allting /.../ Ja, försonas med mig själv. Ensamhet är som kväkarnas tysta andakt, man kan inte genast. Det här, hopträngt mellan två hetsade bullertider, är inte ensamhet. Det är knappt ens att vara ifrån, inte som jag har det med eftersläpning av så mycket. Men det är moment av avspänning och animal glädje och aningen av vad livet kunde vara av solgenomlysthet /.../ och naturligtvis är det fysisk uppbyggnad. Nu först, i kväll, känner jag ödmjukhetskänslan /.../ alstrad av att man är fruktansvärt nedgången. Som det var riktigt med mig under krisen i Shanghai, som det var riktigt med Elin i Lindesberg, med Franciskus, Augustinus, för att hugga till. Avgörande: Det inre ljuset. Jag vill inte vara en levande död och jag måste finna min väg. I varje fall måste man gå en väg för att lära sig hitta, kan inte sitta där man är och spekulera. Känner i detta sammanhang, och med tiden här, att reservkraftstanken börjar fyllas.

Hon klagar också över sin svårighet att skilja på väsentligt och oväsentligt och att hon tycker att varje kontakt med en människa är viktig och då kommer arbetet med Elin biografien lätt i bakgrunden igen.

1957 börjar med en liten ironisk klagan den 2 januari:

Jag kan bara, i bästa fall med ett leende, konstatera att i DN:s och familjens ögon är jag inget märkvärdig. Hemma tas det för givet att jag ska vara uppe halv 7, jobba hela dan, gå ut med Bongo /hunden/ vid midnatt och ändå vara stjärnreporter och det hela. Jaja. Detta är inte bittert menat, bara som en lite besk humoresk. Men känner mig mycket ensam.

Den 24 april 1957 efter en tröttande reportageresa till Japan och Indien skriver hon att hon tänkte:

Nej, jag vill inte bli en av de många splittrade, överansträngda ända in i själen.

Det är inte det jag är född till. Alla lever vi under för starka krav, man kan inte 
pruta på kraven - men man kan ta det hela med mera glädje.

På våren 1957 tar Ruffa studenten och reser sedan till USA för ett års studier. Bland alla journalistiska uppdrag, som Barbro Alving haft detta år, är det ett som hon är direkt tacksam över: Helen Keller. "Det var en underbar människa."

\section{Den 3 januari 1958 skriver Bang i sin dagbok:}

Eckehardt sa - det citerades i kvällsvespern i radio - att om man vill bli en ny människa så är det som att rita en cirkel. Sätter man mittpunkten rätt så blir allt det andra rätt. Han menade Gud som mittpunkten, men liknelsen kan ju också användas på annat. Som i mitt fall, om jag gör som mittpunkt Elin, mitt ansvar för henne (som också växt till den djupaste skulden), samt min kärlek till Ruffa och Loyse. Allt annat, alla människor som dels söker stöd hos mig, dels föröder mig, måste jag undvika tills vidare. Detta känns som en riktig tanke och är det nog. Bara jag orkar in i den.

Den 5 januari, på väg hem från Nockeby, skriver hon att det malde oupphörligt i henne att hon aldrig får en chans att hålla på med sitt eget, bara styra för andra, stipendiearbetet t.ex. och att hon är tvungen att förtjäna pengar. "Är väl en del självömkan i det, och jag vet att det är en själförvållad ynkedom, ekonomiskt och på annat sätt, men jag rår inte för känslan av vanmakt i situationen." Den 7 januari skriver hon, att hon ju egentligen är "så oerhört glad åt livet" men att arbetssituationen "verkligen är vansinnig och utöver varje normal ork." Så länge hon sitter fast i prestationsångesten så länge värker öronnerven vid höger tinning. "När jag släpper den och bestämmer mig för att ta livet ljust på det hela och inte tro att det går att skylla på andra i vad som händer en själv, så släpper sakteliga värken. Så är det."

Den 5 maj 1958 anmäler hon sig till ett kväkarmöte i Söderbärke, "Känner att själen måste det". I början av juni var hon intagen på Sophiahemmet för skrapning och blev liggande där några dagar, åt och sov och läste Elin Wägners romaner och hämtade sig. Den 8 juni skriver hon:

/.../ det hände några märkvärdiga saker på sjukhuset, själsligen. Det hela slutade med att jag - var kväll för övrigt - tackade Gud som ett barn för de dagarna, för att jag fick komma i frid och fick tänka och låta ting sjunka. $\mathrm{Nu}$ vet jag ju att det väsentliga är att sedan hålla fast saker och ting i den röriga verkligheten, man kan inte fly till sjukhuslugn. Och det är svårt, men där måste jag sätta in min strävan.

Den 26 juni står det litet uppgivet: "Slitet sedan åtta år med Elinboken börjar bli smått mardröm. Skruvstäd. Hur bär man sig åt för att inte tappa sugen i skruvstäd?"

Fadern har hela tiden blivit både fysiskt och psykiskt klenare och den 5 augusti avled han, dock utan att Barbro Alving noterar detta i dagboken förrän flera dagar efteråt. "Ingenting har jag orkat skriva här." Strax därpå måste hon låta avliva den älskade hunden Bongo, eftersom han blivit bitsk. I brev till Asta Ekenvall skriver hon från torpet den 24 augusti bl.a.:

Sommaren har ju varit hård, samtidigt som min systers Irlandsresa gjort att jag varit mer hos honom /fadern/ de här veckorna än annars, det är jag oändligt glad för. Men jag är nog en blödig människa, hans gradvisa försvinnande tog så hårt på mig och jag förföljs svårt av minnesbilder nu, framför allt när jag ska somna. Och så har det hänt annat stup i ett. Nils Ohlins död tog oss väldigt, vår sommargranne du vet. Det var en ren chock som högg mänskligt. Och sen har jag måst ta livet av Bongo, det blev på något sätt det värsta och kom mitt i. /.../ Till den psykiska överansträngningen har naturligtvis det här med DN bidragit. Men den saken är biff nu. Jag har visst aldrig riktigt ens gjort klart 
för dig hur genomtänkt och absolut mitt beslut är, fast det naturligtvis är smärtsamt och känns litet svindligt, jag har ju levt hela mitt vuxna liv på den tidningen och blivit vad jag är genom den. Och en tidning är en levande organism, inte en arbetsplats i vanlig mening. Hur som helst: till nyår går jag med bestämda steg, jag har talat med alla vederbörande, Tingsten och min redaktionschef etc. Och jag kommer inte att ångra mig, jag har staplat motskäl kilometerhögt och klarat av dem ett för ett. Det är egentligen mycket enkelt, och mycket skönt, och givetvis på ett sätt en stor lättnad. Det går inte att leva på ett sätt och lära på ett annat, så enkelt kan man säga det.

Hon inser också att tempot på en veckotidning som VJ inte är lika uppskruvat och att hon rimligen kommer att få mer tid för biografien.

Den första gången hon nämner Gunnel Vallquists namn i dagboken är den 20 oktober 1958 då hon noterar att hon skickat Långholmsboken till Gunnel. "Snälla Vår Herre gör att jag får brev snart. Har en känsla att min räddning tillbaka till den djupa fina samhörigheten med människan såsom sådan ligger där. Behöver brinna än en gång, i finaste mening."

På Nyårsdagen 1959, den första f.ö. i det nya hemmet på Östermalm, noterar hon atthon skrivit ett nytt brev till Gunnel.

Jag får be att få se dem när jag vill ha den här utvecklingen klar./.../ Slet sen med stipendiekorrespondensen, den växer som kex i mun. Upptäckte 40 försummelser mitt i natten! Men så här ska det aldrig få bli mer. Även i detta känner jag det annorlunda, inte otålighet som förr. Visst sker det något med mig.

Hon hade gått till Linnégatan, suttit en stund där, bett på knä.

Tårar är min väg, lite av detsamma som jag kände i kyrkan i S:t Benoit när den ensamma orgeltonen fick mig att gå ensam ut på fälten, äntligen inne under vetskapen att av egen kraft går det inte. Orgeltonen sprang liksom ur människans längtan, jag fattig syndare. Satt i tre timmar, fortfarande trög men märkte skillnad, allt är annorlunda nu.

Den 3 januari antecknar hon i dagboken

tre viktiga tanketing. Kom underfund med att det bärande i min längtan att få Elin färdig har kärna av caritas: hon blir glömd, får inte ske. Vet också att min väg i religionen måste gå över Kristus, genom Kristus. Det är en fläkt av det jag känner i kyrkan, därför kommer gråten. Jag ber varje kväll för vad det är värt. Det tredje: måste sluta oroa mig för att jag kanske arbetar ihjäl mig och nöter sönder skallen, helt enkelt tro att Gud hjälper mig där om jag ärligen tar alla mina ansvar. Förtröstan. Det är som psalmen säger: Allt ju vilar i min Faders händer.

Den 29 mars, påskafton:

Jag måste försöka slänga ner några rader, det händer mig så mycket invärtes. Det viktigaste: grammofontimmen ensam med Händels Messias. Satt med krucifixet, måste vara så var morgon en stund.

Fyra ting.

1. Man måste erkänna att man fått Guds härlighet också inom sig, inte bara synden. Mycket svårare.

2. Jag ska ha kärleken, detta nya, tron och Kristus i mitt väsens innersta lager, under alla mina förehavanden. Inte brottas med hur sysslorna ska kunna bli direkta manifestationer, för där går jag bet.

3. Vill skriva i VJ om att kärnvapenkampanjen blivit förgiftad och det får 
inte vara så. Vi ska se till uppsåten på båda håll, och den ärliga våndan.

4. Måste gå igenom trosbekännelsen, fråga om Gunnels förhållande till evigt liv och köttets uppståndelse.

Vid pingsten 1959 konverterade Barbro Alving men det står inte ett ord om detta i dagboken. Däremot skriver hon utförligt om sin syn på katolicismen i brev den 5 juli 1959 till dottern Ruffa, som tydligen också funderar på att konvertera eller i varje fall vill veta mer om katolicismen.

Det finns sjutusen patentskäl mot katolicismen i Sverige, det är liksom med rysskräcken från Karl XII:s tid. De flesta har ingen aning vad de talar om och säger bara efter den allmänna jargongen.

De flesta motskälen ligger också på det s.k. världsliga planet: Hur kan man tillhöra en kyrka, en ruskig kyrka, som förbjuder skilsmässa helt grymt, och är emot barnbegränsning i den svältande världen, och allt möjligt sånt där. Börjar man forska litet i de sakerna så hittar man ordentliga svar som välter upp och ner på angreppen - inte minst det utomordentliga svaret att i många sådana där ting - däribland det här med barnbegränsningen - har man som katolik all rätt i världen att kritisera kyrkan och inom dess murar kämpa för en annan syn. Det finns en stor och växande falang inom katolska kyrkan som just är radikal och arg på påvebeslut i den sortens frågor, och till den vill jag naturligtvis höra. Gunnel Vallquist gör det i högsta grad, och det är många fler.

Men det är ju inte det som det innerst inne handlar om och som är det viktiga och det avgörande. Vad det är vill jag prata med dig om. Kanske kan du ta som utgångspunkt bara detta - du som känner mig så bra som din mamma - att det ju måste vara något existerande och riktigt och icke överspänt när en människa som jag känner sig som om den kommit hem efter trettio års sökande. Känner sig ställd inför oerhörda andliga krav som är en lycka bara de, och samtidigt mottagen i den kärlek som är ursprunget till all kärlek i denna värld.

Det hela och så mycket kan jag väl återigen säga - är ju att man tror, och det i sin tur kan gå till så att man i en sekunds klarhet förstår vad Kristi gestalt och liv innebar. Hans ord och död går helt enkelt inte att förklara om han inte är direkt av Gud, är Guds son som tog på sig bördan att leva under människans villkor och dö för oss, för det var enda sättet att få människan att fatta något, vi är ju oförbätterligt kortsynta om vi ska klara oss med vårt eget lilla förstånd, som Ruffa kanske kan tänka sig. Så enkelt tedde det sig plötsligt för mig (jag satt i ett flygplan av alla ställen, dessutom) och då blev nästa steg ännu enklare och gick alldeles av sig själv: han dog för mig - då är väl det minsta jag kan göra att älska honom! Sen är man fast! Älskade lilla Ruffa, var inte rädd att jag ska predika, jag slutar nu. Men några rader tyckte jag ändå att jag ville skriva till mitt enda barn.

Tack snälla söta rara du för att du inte tycker om boxning. Det är ändå jävligare i närbild.

Jag har medvetet citerat ett så här långt avsnitt ur brevet, därför att det är det enda ställe där Barbro Alving samlat ger sin syn på konversionen och katolicismen. Typiskt är också att hon inte blir patetisk utan omedelbart dyker ner i boxningens avigsidor, med ett synnerligen kraftigt ordval dessutom! Bakgrunden var att hon varit utsänd från VJ att rapportera från boxningsmatchen Ingo och Floyd och gjorde det med sådan glöd och sådant avståndstagande att hon bidrog till att proffsboxningen förbjöds i Sverige.

Mot slutet av året tar hon upp arbetet med biografin igen, men avbrotten kommer precis som förut. Den 15 december 1959 skriver hon i dagboken: 
Ensam igår kväll för att jobba med en översättning och framför allt tänka, komma underfund med min religiösa situation. Starkt behov vara ensam. Satt i morse och funderade, var mycket nervös och rörig, först. Läste mässan och försökte litet i Sous le regard de Dieu men var disträ. Äntligen lossnade det. Jag fann nyckelordet, mitt nyckelord? Jag lägger, har lagt, mitt liv i Guds hand. Gud vet ju mina resurser, min begränsning, allt. Jag behöver inte stånga huvudet mot en vägg av förtvivlan över alltings myckenhet, splittringen, svårigheten att koncentrera mig och få frid i religiöst liv. Han vet och ser att jag gör så gott jag kan.

Det blev ett stort lugn över allting. Jag är så glad åt livet!

Detta är den sista anteckningen i de utgivna fyra volymerna Personligt.

Som kommentar till att Elin Wägner-biografien aldrig kunde slutföras av Barbro Alving skriver hennes dotter i en Efterskrift, att Barbro Alving var journalisten, vars styrka det är att berätta om vad som tilldrar sig i nuet. "Att vara där det händer, när det händer." Att sätta färg på och ge närvarokänsla åt nuets ofta dramatiska och historiska händelser. Trots sjukdom och värk och långa sjukhusvistelser fortsatte hon under 60-talet att göra stora reportage för VJ: Agadir 1960, Eichmannprocessen 1961, Vietnam 1967 för att bara nämna några exempel. Tillsammans med fotografen Anders Engman gjorde hon också reportage från Mellanöstern 1969 och från Afrika 1971.

Våren 1983 drabbades hon, som jag redan tidigare nämnt, av afasi och kunde inte längre skriva. Fyra år senare avled hon den 22 januari 1987. De memoarer som hon planerat under rubriken Som det verkligen var och samlat material till kom inte heller ut. Dottern Ruffa Alving-Olin och den goda vännen Birgit Petri sammanställde i stället brev och dagboksanteckningar till de fyra volymerna Personligt, som kom ut åren 1990 (del 1 och 2), 1991 (del 3) och 1992 (del 4).

\section{(C) Elisabeth Stenborg}

